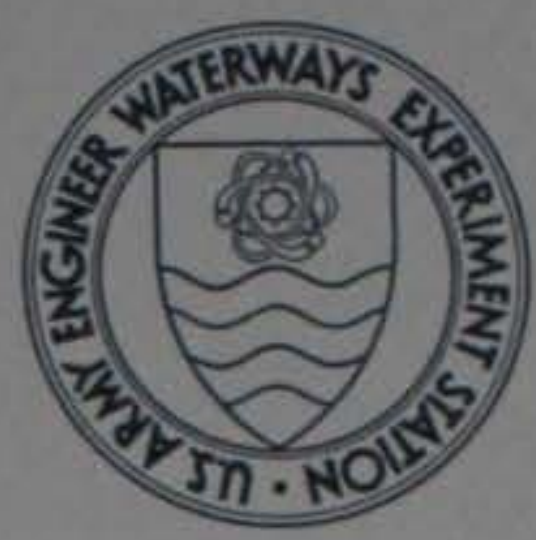

\title{
LOADING RATE EFFECTS ON COMPRESSIBILITY OF SAND
}

\author{
by
}

J. G. Jackson, Jr., J. Q. Ehrgott, Behzad Rohani

Structures Laboratory

U. S. Army Engineer Waterways Experiment Station

P. O. Box 63l, Vicksburg, Miss. 39180

November 1979

Final Report

Approved For Public Release; Distribution Unlimited

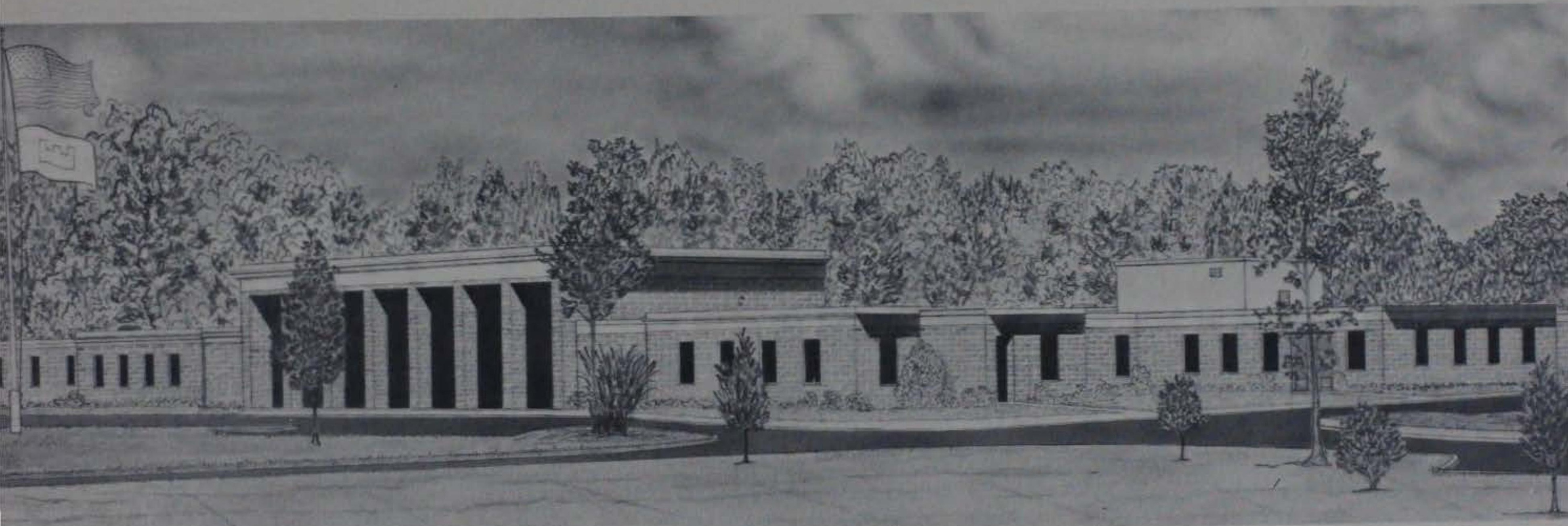

Prepared for Defense Nuclear Agency

Washington, D. C. 20305

Under Subtask SB209, Work Unit 39

LBRAFY BRANCH

TECHNICAL INFORMATION CENTER

US ARMY ENGINEER WATERWAYS EXPERIMENT STATION VICKSBURG. MISSISSIPPI 


\begin{tabular}{|c|c|}
\hline REPORT DOCUMENTATION PAGE & $\begin{array}{l}\text { READ INSTRUCTIONS } \\
\text { BEFORE COMPLETING FORM }\end{array}$ \\
\hline $\begin{array}{l}\text { 1. REPORT NUMBER } \\
\text { Miscellaneous Paper SL-79-24 }\end{array}$ & 3. RECIPIENT'S CATALOG NUMBER \\
\hline \multirow{2}{*}{$\begin{array}{l}\text { 4. TITLE (and Subtitie) } \\
\text { LOADING RATE EFFECTS ON COMPRESSIBILITY OF SAND }\end{array}$} & $\begin{array}{l}\text { 5. TYPE OF REPORT A PERIOD COVERED } \\
\text { Final report }\end{array}$ \\
\hline & 6. PERFORMING ORG. REPORT NUMBER \\
\hline $\begin{array}{l}\text { 7. AUTHOR(s) } \\
\text { John G. Jackson, Jr. } \\
\text { John Q. Ehrgott } \\
\text { Behzad Rohani }\end{array}$ & 8. CONTRACT OR GRANT NUMBER(s) \\
\hline $\begin{array}{l}\text { 9. PERFORMING ORGANIZATION NAME AND ADDRESS } \\
\text { U. S. Army Engineer Waterways Experiment Station } \\
\text { Structures Laboratory } \\
\text { P. O. Box } 631 \text {, Vicksburg, Miss. } 39180\end{array}$ & $\begin{array}{l}\text { 10. PROGRAM ELEMENT PROJECT, TASK } \\
\text { AREA \& WORK UNIT' NUMBERS } \\
\text { Subtask Y99QAXSB209 } \\
\text { Work Unit } 39\end{array}$ \\
\hline \multirow{2}{*}{$\begin{array}{l}\text { 11. CONTROLLING OFFICE NAME AND ADDRESS } \\
\text { Director } \\
\text { Defense Nuclear Agency } \\
\text { Washington, D. C. } 20305\end{array}$} & $\begin{array}{l}\text { 12. REPORT DATE } \\
\text { November } 1979 \\
\end{array}$ \\
\hline & $\begin{array}{l}\text { 13. NUMBER OF PAGES } \\
20\end{array}$ \\
\hline \multirow[t]{2}{*}{ 14. MONITORING AGENCY NAME \& ADDRESS(if different from Controlling Office) } & $\begin{array}{l}\text { 15. SECURITY CLASS. (of this roport) } \\
\text { Unclassified }\end{array}$ \\
\hline & $\begin{array}{l}\text { 15a. DECLASSIFICATION/DOWNGRADING } \\
\text { SCHEDULE }\end{array}$ \\
\hline
\end{tabular}

\section{DISTRIBUTION STATEMENT (of this Report)}

Approved for public release; distribution unlimited.

\section{DISTRIBUTION STATEMENT (of the abstract entered in Block 20, if different from Report)}

\section{SUPPLEMENTARY NOTES}

This research was sponsored by the Defense Nuclear Agency under Subtask Y99QAXSB209, "Propagation of Ground Shock Through Soils and Rock," Work Unit 39, "Test Equipment and Techniques."

19. KEY WORDS (Continue on reverse side if necessary and identify by block number)

Compressibility (soils) Stress-strain curves

Dynamic loads Uniaxial strain tests

Loading rate Viscosity

Sands Wave propagation

Soil mechanics

20. ABSTRACT (Continue on reverse side if necessary and identify by block number)

Stress-strain curves from 61 uniaxial strain tests are presented which depict the response of three dry sands to intense transient pressures; the loadings ranged from $10 \mathrm{MPa}$ to $80 \mathrm{MPa}$ and were applied with rise times ranging from a few tenths of a millisecond to a few minutes. Equipment and techniques used to conduct the tests and to assess the effect of wave propagation on the measurements are described. The data show that the resistance of dry sands to 
20. ABSTRACT (Continued).

compression increases dramatically when loading rise times are less than $1 \mathrm{msec}$, and that the character of the stress-strain relation shifts rapidly from a "stiffening" response (curvature concave to stress axis) to a "yielding" response (curvature concave to strain axis). The stress-strain response of a relatively simple rate-dependent rheologic model is shown to be in good agreement, both qualitatively and quantitatively, with the measured results. 
This paper was prepared for presentation during Session No. 36 on Mechanics of Granular Media and the Related Contact Problems at the American Society of Civil Engineers Annual Convention and Exposition in Atlanta, Georgia, 22-26 October 1979.

The paper describes work performed by personnel of the Geomechanics Division, Structures Laboratory (SL), U. S. Army Engineer Waterways Experiment Station (WES), for the Defense Nuclear Agency (DNA) under Subtask Y99QAXSB209, "Propagation of Ground Shock Through Soils and Rock." It was prepared by Dr. J. G. Jackson, Jr., Mr. J. Q. Ehrgott, and Dr. Behzad Rohani; Dr. Jackson made the oral presentation.

Mr. Bryant Mather was Chief of SL during the preparation of this paper. The Commander and Director of WES was COL Nelson P. Conover, CE, and the Technical Director was Mr. F. R. Brown. Dr. George W. Ullrich was the Subtask Manager for DNA. 


\author{
By J. G. Jackson, Jr., ${ }^{1}$ M.ASCE, J. Q. Ehrgott, ${ }^{2}$ M.ASCE, \\ and Behzad Rohani, ${ }^{3}$ M.ASCE
}

\title{
INTRODUCTION
}

Soil compressibility is usually determined in the laboratory by axially compressing cylindrical soil samples in a uniaxial strain device ${ }^{4}$ and measuring their axial deformation. For practical applications, the laboratory tests should reflect the stress levels, loading rates, and drainage conditions of interest.

As part of a pioneering research effort at MIT to define the response of soils for problems associated with ground shock from nuclear explosions, Whitman developed a dynamic uniaxial strain device based on a novel

1 Supv. Res Civil Engr, Geomechanics Div, Structures Lab, U. S. Army Engineer Waterways Experiment Station, Vicksburg, Mississippi.

2 Res Civil Engr, Geomechanics Div, Structures Lab, U. S. Army Engineer Waterways Experiment Station, Vicksburg, Mississippi.

3 Res Civil Engr, Geomechanics Div, Structures Lab, U. S. Army Engineer Waterways Experiment Station, Vicksburg, Mississippi.

4 Although frequently referred to in conventional soil mechanics practice as a consolidometer, oedometer, or one-dimensional compression device, the test boundary conditions are most accurately described from a continuum mechanics viewpoint by the term uniaxial strain. 
multiple-reflection technique $(1,2)$. If the rise time of the applied loading pulse is long relative to the time required for a stress wave to propagate back and forth between the rigid-bottom boundary and the free-surface boundary, then inertial stresses can be neglected and stress and strain within the specimen can be readily deduced as a function of time from external measurements of applied pressure and surface deflection. The MIT gas-fluid loading system permitted dynamic pressures up to about $1.4 \mathrm{MPa}$ to be applied with rise times on the order of $15 \mathrm{msec}$. Schindler subsequently developed a similar test device at WES which used a piston-fluid loading system to develop 2.1-MPa pressures in about $3 \mathrm{msec}(3)$.

Experimental results for dry sands show that the stress-strain curves, starting from some initial prestress, are S-shaped, with yielding for small stress changes and stiffening for large stress changes (4). The secant modulus of dry sand for a rapid loading (say 10-msec rise time) is usually on the order of 5 to 40 percent greater than that for a slow loading (several minutes rise time); typical values previously reported for such dynamic-to-static modulus ratios are given in Table 1 . In summarizing the MIT findings, Whitman (8) concludes that time-dependent effects can generally be ignored for problems involving dry granular materials subjected to dynamic loadings with millisecondrange rise times, provided that the stress-strain relation used in the analysis is obtained from a test in which loading and unloading take place in $30 \mathrm{msec}$ or less. But he warns that there is evidence to indicate that time effects become very important when the duration of the stress pulse drops to about $1 \mathrm{msec}$ or less and cites a need for more adequate study of time-dependent effects during uniaxial strain tests with large stress changes and submillisecond rise times. 


\begin{tabular}{|c|c|c|c|c|c|}
\hline $\begin{array}{l}\text { Sand type and } \\
\text { source of data } \\
\text { (1) }\end{array}$ & $\begin{array}{c}\text { Relative } \\
\text { density } \\
\% \\
(2) \\
\end{array}$ & $\begin{array}{c}\text { Initial } \\
\text { prestress } \\
\mathrm{MPa} \\
(3)\end{array}$ & $\begin{array}{l}\text { Live } \\
\text { stress } \\
\mathrm{MPa} \\
(4)\end{array}$ & $\begin{array}{l}\text { Dyn stress } \\
\text { rise time } \\
\text { msec } \\
\text { (5) }\end{array}$ & $\begin{array}{c}\text { Dyn-to-static } \\
\text { modulus } \\
\text { ratio } \\
(6)\end{array}$ \\
\hline $\begin{array}{l}\text { Uniform beach sand, SP, } \\
\text { median diam }=0.34 \mathrm{~mm} \\
\text { (Moore--ref 5) }\end{array}$ & $\begin{array}{l}97 \\
38 \\
70 \\
70 \\
70\end{array}$ & $\begin{array}{l}0.10 \\
0.10 \\
0.10 \\
0.10 \\
0.69\end{array}$ & $\begin{array}{l}0.34 \\
0.34 \\
0.34 \\
0.69 \\
0.07\end{array}$ & $\begin{array}{r}\sim 10 \\
\sim 10 \\
-10 \\
8 \\
10\end{array}$ & $\begin{array}{l}1.04 \\
1.10 \\
1.15 \\
1.08 \\
1.38\end{array}$ \\
\hline $\begin{array}{l}\text { Uniform fine sand, SP, } \\
\text { median diam }=0.24 \mathrm{~mm} \\
\text { (Schindler--ref } 6 \text { ) }\end{array}$ & 94 & 0.0 & 2.07 & 25 & 1.08 \\
\hline $\begin{array}{l}\text { Fine silty sand, SM, } \\
\text { median diam }=0.14 \mathrm{~mm} \\
\text { (Jackson--ref } 7 \text { ) }\end{array}$ & 58 & 0.0 & 2.07 & 5 & 1.20 \\
\hline
\end{tabular}

\section{SCOPE OF THIS PAPER}

Equipment is described for conducting multiple-reflection type uniaxial strain tests to much higher pressures and at much faster loading rates than those discussed above. Experimental results are presented from tests conducted on three dry remolded sands (see Fig. 1) which show that the resistance to compression, or stiffness, of these materials increases dramatically when the loading times drop below a millisecond. Results for 20-40 Ottawa Sand are analyzed with a one-dimensional plane wave propagation computer code to determine if the measurements were adversely affected by inertia effects. Results from 40 tests on $\mathrm{HH}$ Clayey Sand are analyzed to determine if the observed trends are statistically significant. Finally, results from tests on FH2 Backfill Sand spanning a wide range of submillisecond loadings are compared with the response of a three-element rheologic model. 


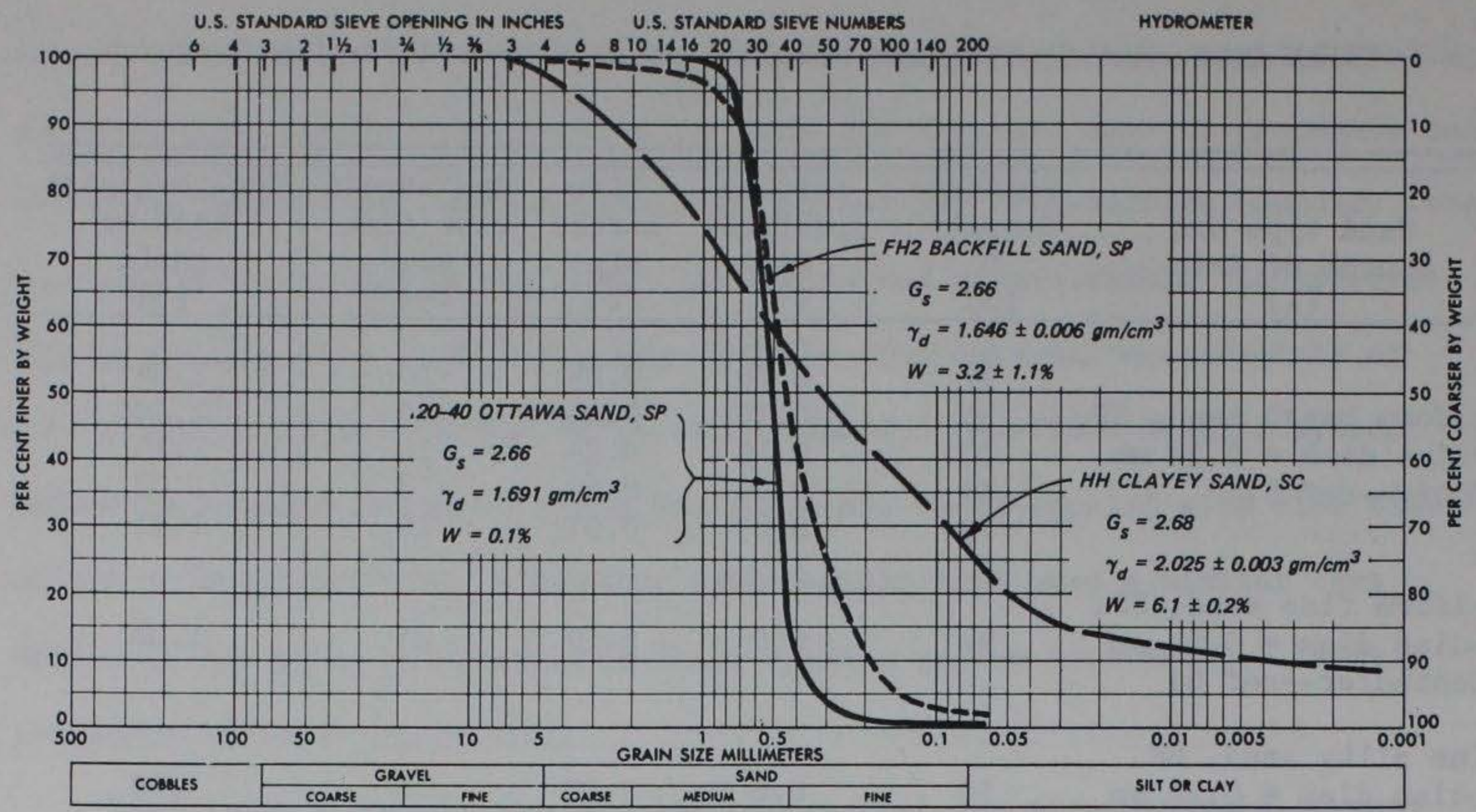

Fig. 1--Gradation, Classification, and Composition Data for Test Materials.

\section{TEST DEVICES AND TECHNIQUES}

The 100-MPa, ram-loaded uniaxial strain test device shown in Fig. 2 was developed in 1969 and is similar in concept to the device described in detail by Schindler (6). The gas-driven ram can apply piston loads up to 450,000 N with rise times as fast as $3 \mathrm{msec}$ and decay times as fast as $20 \mathrm{msec}$; the piston, in turn, produces a planar pressure pulse in an oil-filled chamber which uniformly loads the surface of the membrane-sealed soil specimen. Oil pressures are measured with a flush-mounted, diaphragm-type pressure transducer. The specimens are laterally constrained by the thick steel walls of the bottom assembly. The specimens are quite thin ( $1.27 \mathrm{~cm} \mathrm{high),} \mathrm{in} \mathrm{order} \mathrm{to}$ minimize the transit time of propagating stress waves, and have a small heightto-diameter ratio $(1: 7.6)$, in order to prevent sidewall friction from influencing center deflections. Center deflections are measured with an LVDT transducer located totally within the pressurized oil chamber and mounted directly on the soil specimen container. 

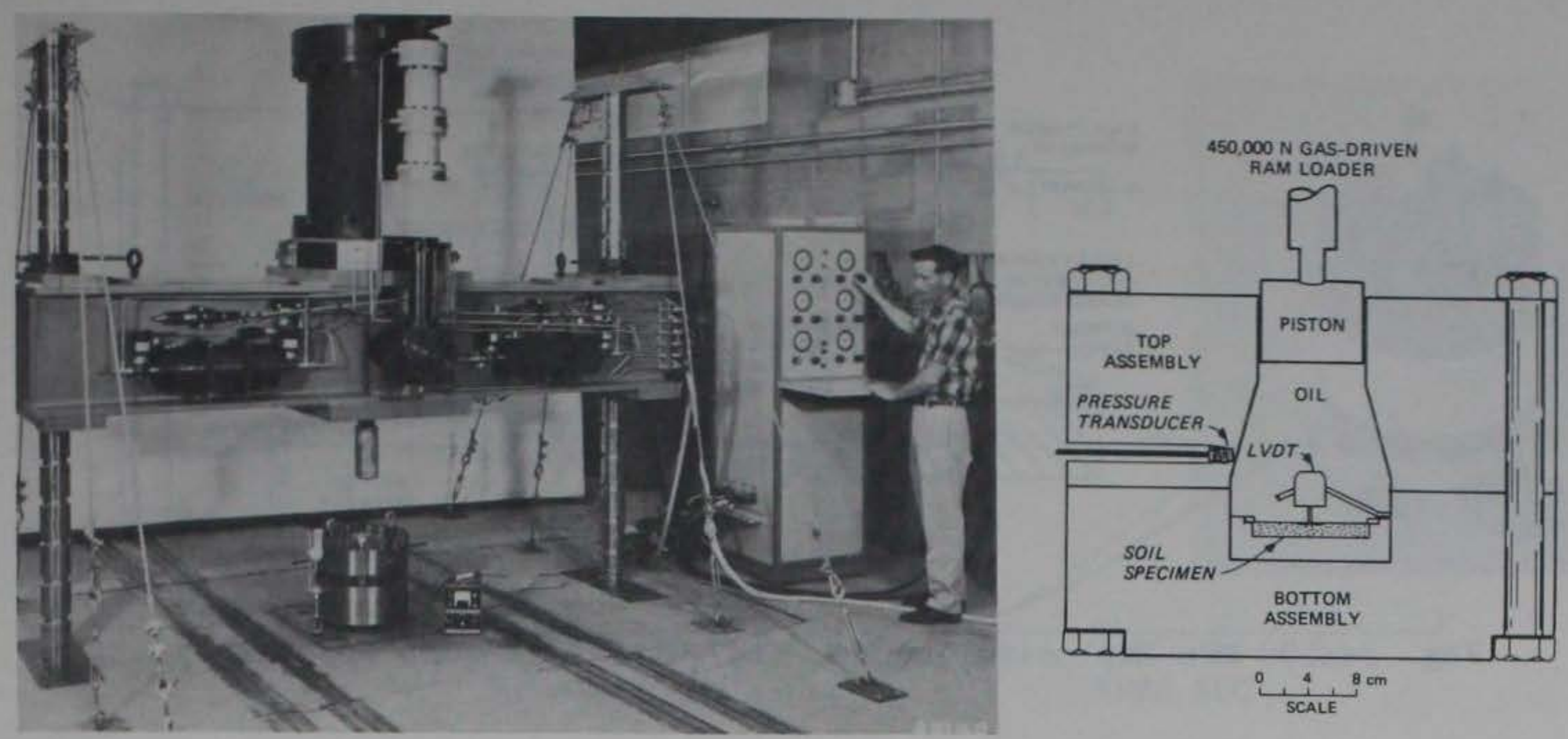

Fig. 2--100 MPa Ram-loaded Uniaxial Strain Test Device.

The 100-MPa, explosive-loaded uniaxial strain test device shown in Fig. 3 was developed in 1978. Instead of a gas-driven ram, an explosive charge is used to drive a piston into the oil, which in turn pressurizes the specimen. The device consists of three separate assemblies which are joined by 16 high-strength bolts. The top assembly contains the explosive charge and chamber, three gas expansion chambers, flow controls and metering orifices, and the oil-pressurizing piston. Pressures can be varied up to $100 \mathrm{MPa}$ by varying the size of the charge; rise and decay times as fast as $0.3 \mathrm{msec}$ can be obtained with the gas flow controls. The middle assembly contains the oil chamber, the flush-mounted pressure transducer, and the electrical leads to the LVDT transducer. The lower assembly holds the test specimen container.

The same soil specimen container and deflection measurement system were used in both the explosive-loaded and the ram-loaded devices. Preweighed quantities of sand were alternately spooned and tamped into the container and the surface leveled with a straightedge. A 5-mm-thick rubber membrane attached to an aluminum LVDT footing assembly was placed over the specimen and sealed around the edges with a steel clamp containing two 0-rings. 

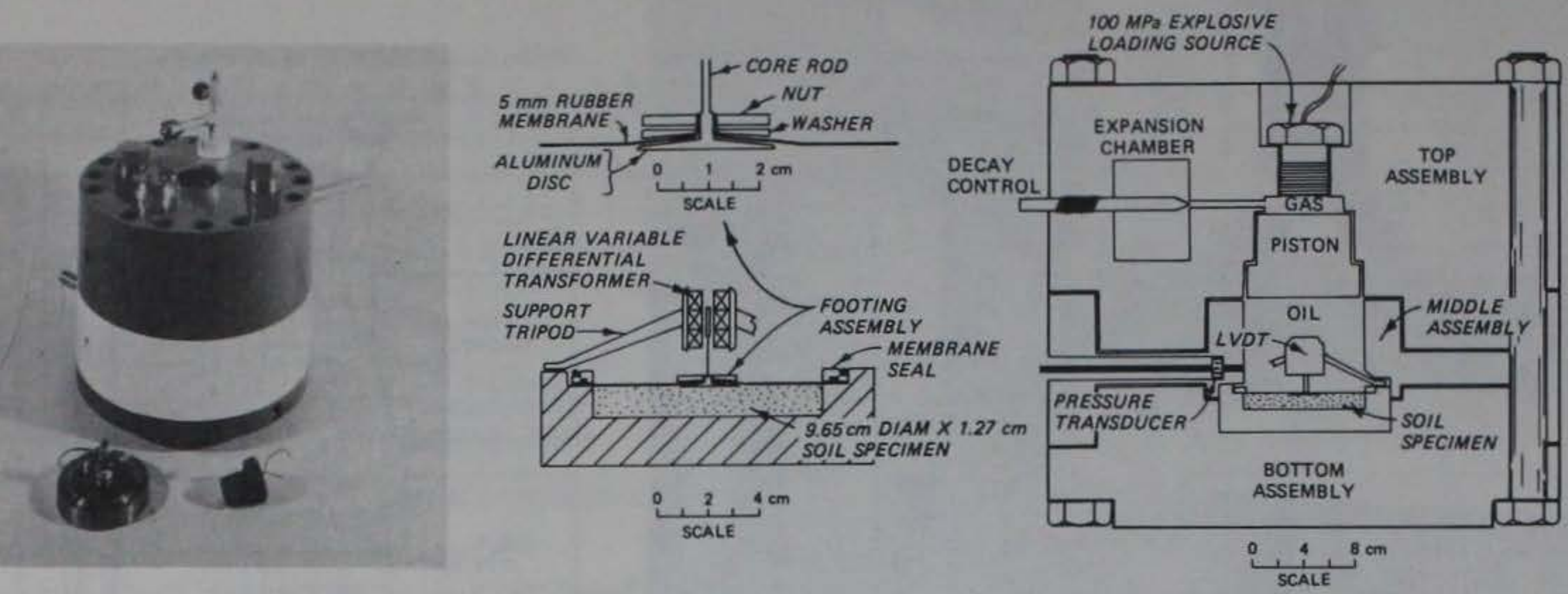

Fig. 3--100 MPa Explosive-loaded Uniaxial Strain Test Device.

The LVDT support tripod was then positioned to complete the assembly. Details are shown in the center of Fig. 3.

As depicted in Fig. 4, oil pressure, P, and LVDT deflection, $\Delta H$, were recorded continuously during each test. The surface of the specimen was uniformly loaded with $\mathrm{P}(\mathrm{t})$ and was assumed to uniformly deflect an amount, $\Delta \mathrm{H}(\mathrm{t})$; radial strains were assumed to be zero. Assuming inertial stresses to be negligible, axial stress, $\sigma$, within the specimen was uniform and equal to $P$; axial strain, $\varepsilon$, was assumed to be uniform and equal to $\Delta H / H$.
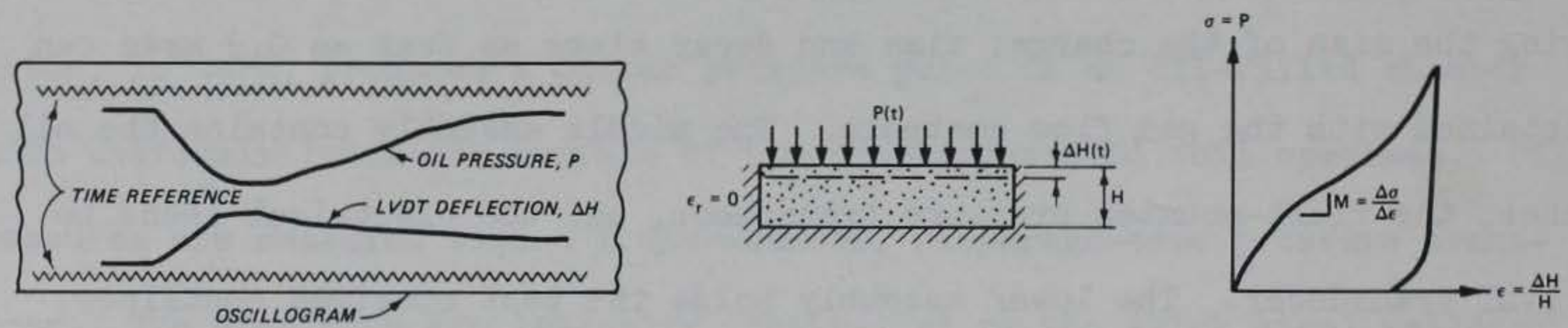

Fig. 4--Measurements, Boundary Conditions, and Data Interpretation for Uniaxial Strain Tests.

\section{TESTS ON 20-40 OTTAWA SAND}

Six tests were conducted on air-dried specimens of 20-40 0ttawa Sand with an initial void ratio of 0.572 ; stress-strain and pressure-time plots are given in Fig. 5. Results from the two static tests are in excellent agreement 

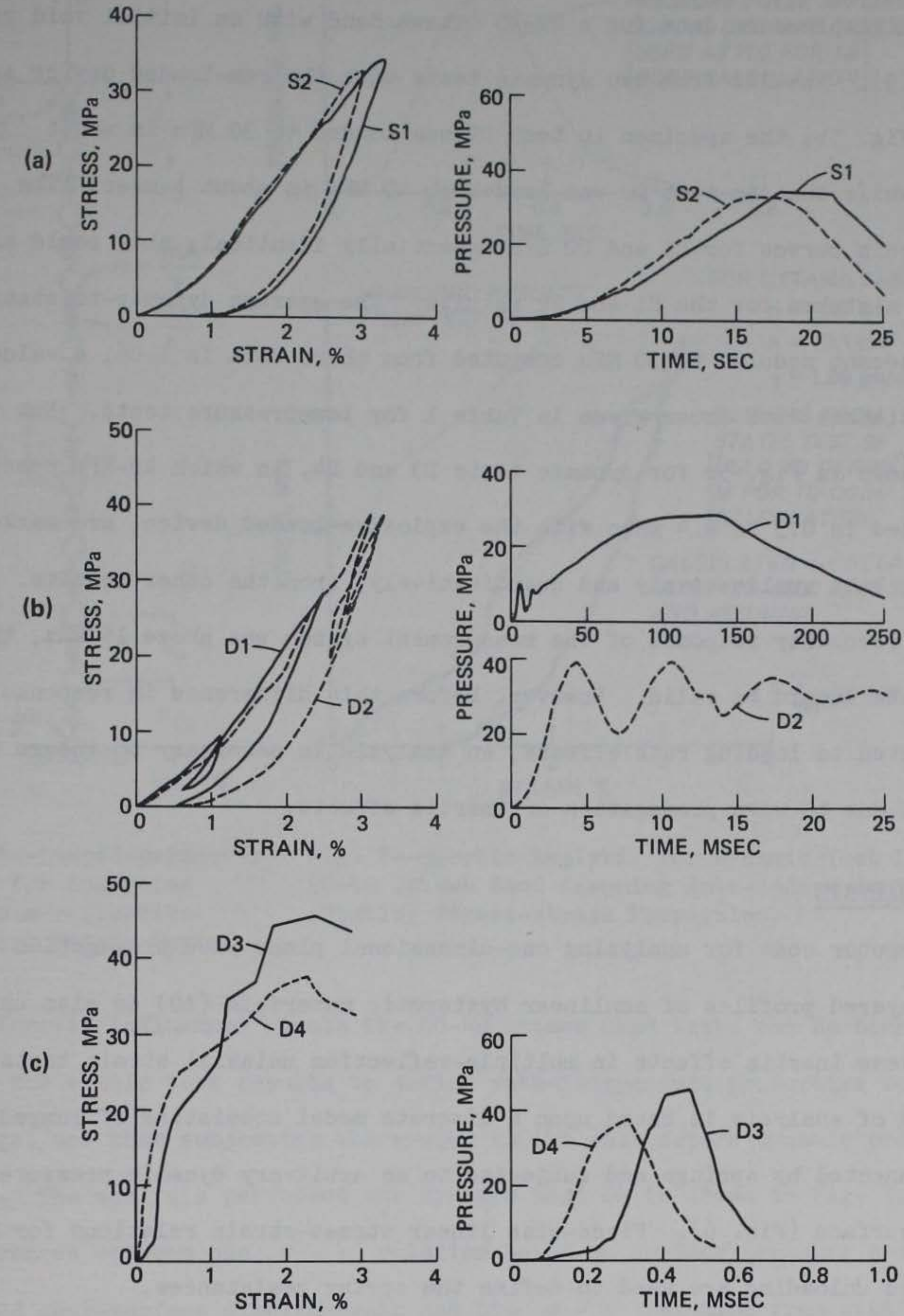

Fig. 5--Uniaxial Strain Test Results for 20-40 Ottawa Sand. 
with each other (see Fig. 5a); they also agree quite well with previously reported high-pressure data for a 20-40 0ttawa Sand with an initial void ratio of 0.527 (9). Results from two dynamic tests with the ram-loaded device are shown in Fig. 5b; the specimen in test DI was loaded to $30 \mathrm{MPa}$ in about $100 \mathrm{msec}$ while that in test D2 was loaded to $40 \mathrm{MPa}$ in about $4 \mathrm{msec}$. The stress-strain curves for D1 and D2 are essentially identical; they could also be easily mistaken for the $\mathrm{S} 1$ and $\mathrm{S} 2$ results. The average dynamic-to-static ratio of secant modulus to $30 \mathrm{MPa}$ computed from these data is 1.06 , a value quite consistent with those given in Table 1 for low-pressure tests. But the results shown in Fig. 5c for dynamic tests D3 and D4, in which 40-MPa pressures were applied in 0.3 to $0.4 \mathrm{msec}$ with the explosive-loaded device, are markedly different, both qualitatively and quantitatively, from the other results. Since the frequency response of the measurement system was above $15 \mathrm{kHz}$, the measurements should be valid. However, before this difference in response can be attributed to loading rate effects, an analysis is necessary to insure that it was not due to wave propagation or inertia effects.

\section{INERTIA ANALYSIS}

A computer code for analyzing one-dimensional plane wave propagation through layered profiles of nonlinear hysteretic materials (10) is also used at WES to assess inertia effects in multiple-reflection uniaxial strain tests. The method of analysis is based upon a discrete model consisting of lumped masses connected by springs and subjected to an arbitrary dynamic pressure at the free surface (Fig. 6). Piece-wise linear stress-strain relations for both loading and unloading are used to define the spring resistances. 


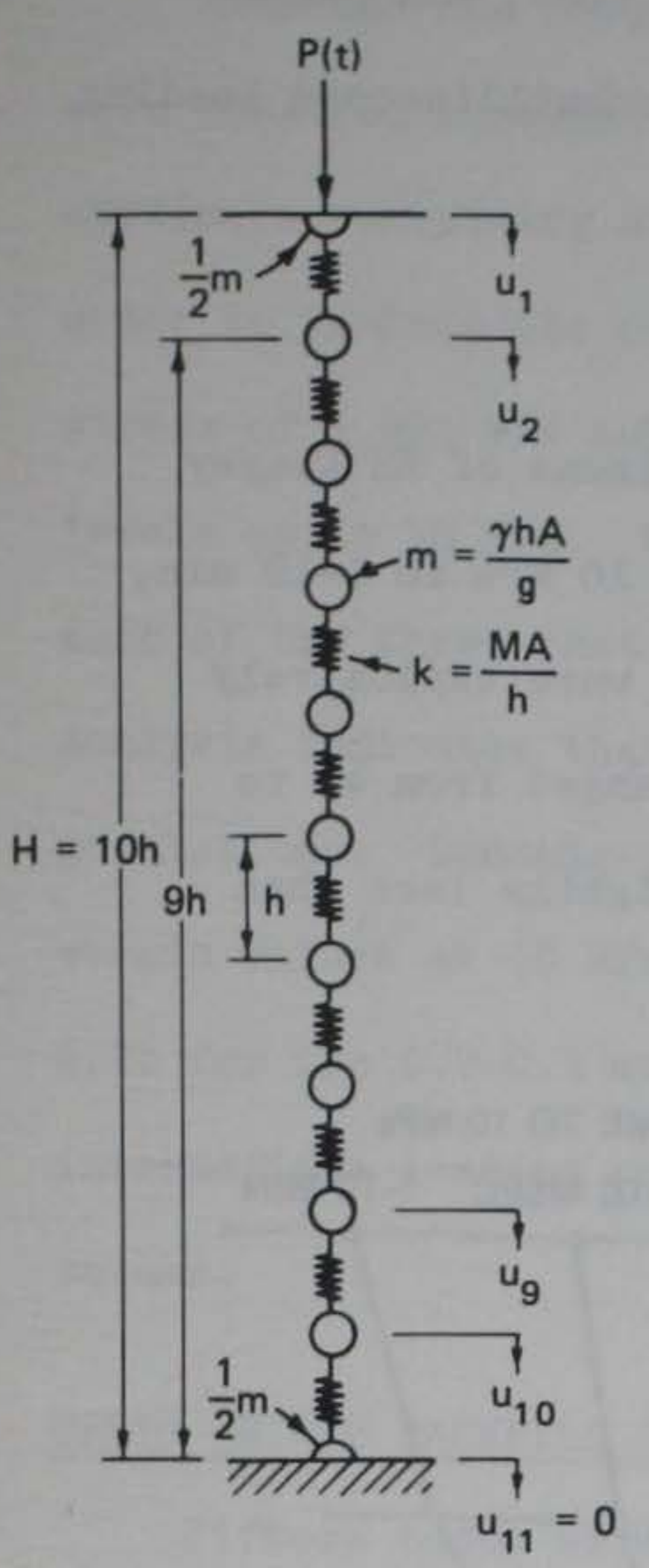

Fig. 6--Lumped-parameter Model for Analyzing Multiple-reflection Uniaxial Strain Tests.
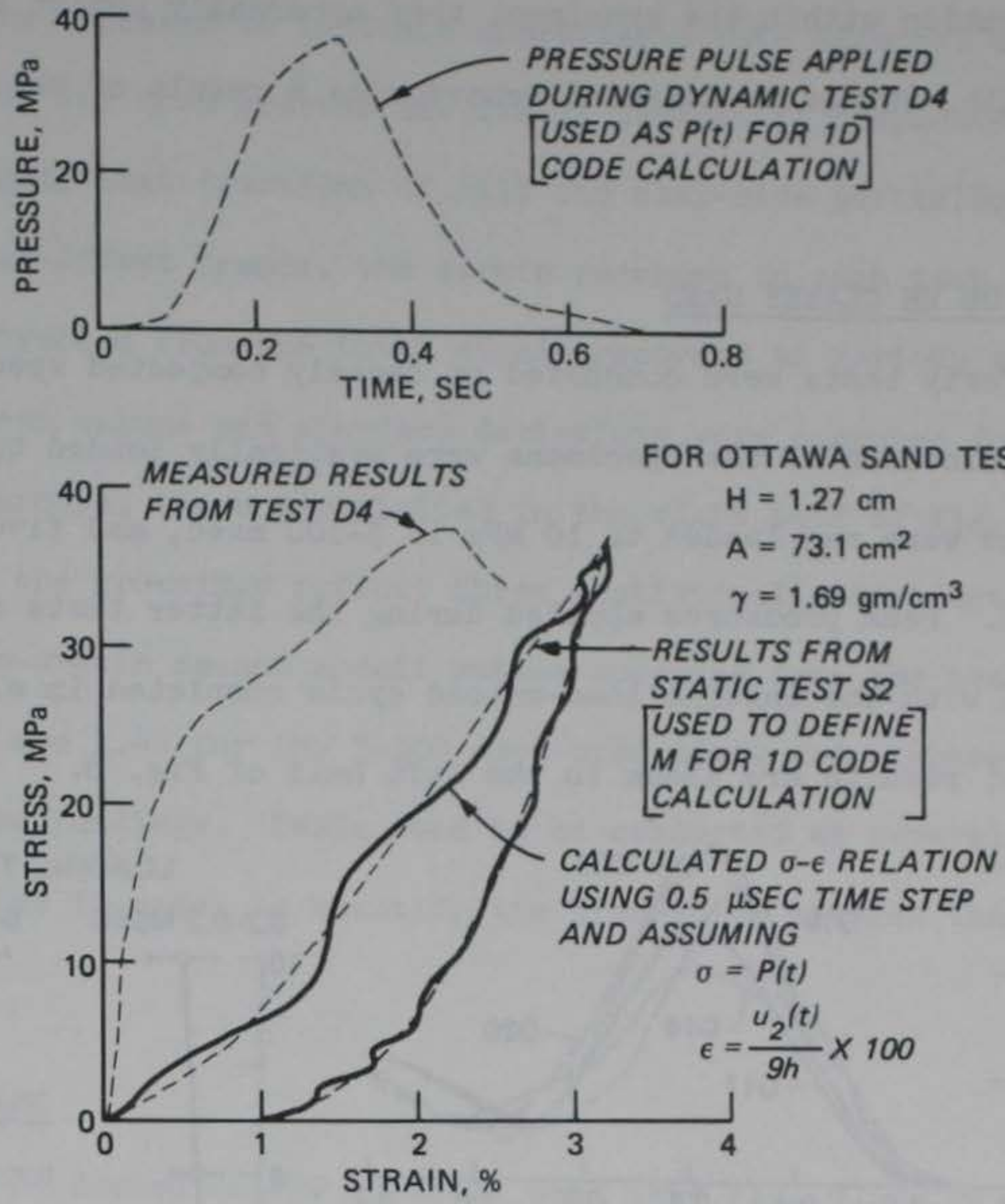

Fig. 7--Inertia Analysis for Dynamic Test D4 on 20-40 Ottawa Sand Assuming Rate-independent (Static) Stress-strain Properties.

Inertia influences within the 20-40 0ttawa Sand tests can be bounded by using the static test results to define rate-independent properties for the springs, and then subjecting the system to the most severe dynamic pressure pulse. The analysis performed for dynamic test D4 is shown in Fig. 7. The differences between the $\sigma-\varepsilon$ relation based on surface pressure and calculated near-surface displacements and the $\sigma-\varepsilon$ relation from static test S2 (which was specified as the "true" property) represent the maximum potential measurement errors due to inertia effects. Thus the measured results from tests D3 and D4 on 20-40 Ottawa Sand were not significantly affected by wave 
propagation within the specimen; they apparently depict a real, and rather dramatic, change in material behavior as a result of the submillisecond loading times.

\section{TESTS ON HH CLAYEY SAND}

Forty tests were conducted on densely compacted specimens of HH Clayey Sand; nineteen of the specimens were statically loaded to $10 \mathrm{MPa}$ in 1-10 min, sixteen were ram-loaded to $10 \mathrm{MPa}$ in $5-100 \mathrm{msec}$, and five were explosively loaded. Peak pressures applied during the latter tests ranged from 40 to $60 \mathrm{MPa}$ with the initial load-unload cycle completed in slightly less than I msec; results are shown in the left half of Fig. 8.
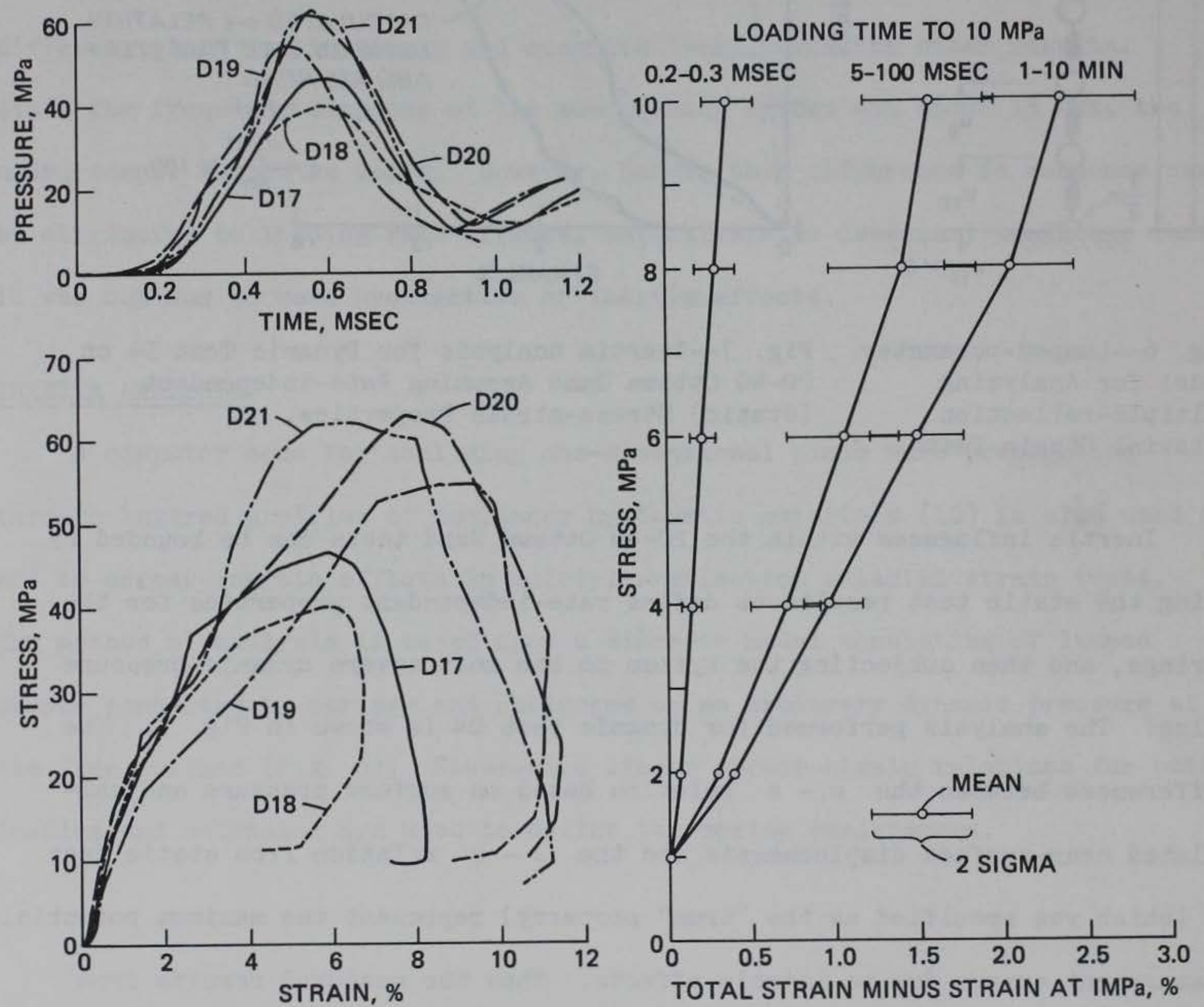

Fig. 8--Uniaxial Strain Test Results for HH Clayey Sand. 
Although the results appeared to indicate appreciable rate effects, they were obscured somewhat by the data scatter inevitably present in compacted specimens containing significant fractions of silt and clay-size particles. In order to isolate the rate-effect trends, the strain recorded in each test at a stress of $1 \mathrm{MPa}$ was subtracted from the total strain recorded at various stress levels up to $10 \mathrm{MPa}$. Mean values and standard deviations were computed for each of the three test groups; these are plotted in the right half of Fig. 8 . Analysis indicates that the groupings reflect three statistically-distinct populations. Dynamic-to-static secant moduli ratios computed from the mean strain values at $10 \mathrm{MPa}$ are 1.45 for the $5-100 \mathrm{msec}$ rise times and a whopping 6.28 for the $0.2-0.3 \mathrm{msec}$ loadings. Tests need to be conducted at several intermediate loading rates in order to quantify the transition between these values.

\section{TESTS ON FH2 BACKFILL SAND}

Fifteen tests were conducted on FH2 Backfill Sand (see Fig. 9). The slowest loadings were applied in test $\mathrm{Sl}$ (about $20 \mathrm{MPa}$ in $35 \mathrm{sec}$ ) and test $\mathrm{S} 2$ (about $40 \mathrm{MPa}$ in $50 \mathrm{sec}$ ). Tests S3 and $\mathrm{S} 4$ were performed with loadings to 35 $\mathrm{MPa}$ in about $20 \mathrm{sec}$. Results for these four static tests are plotted in Fig. 9a. The specimen in dynamic test DI was subjected to an $80-\mathrm{MPa}$ pressure in about $4 \mathrm{msec}$ with the ram loader. By varying the size of the charge, the weight and size of the piston, and the flow control settings, it was possible to produce a range of loading rates with the explosive-loaded device, e.g., 10 $\mathrm{MPa}$ in about $1 \mathrm{msec}$ in tests $\mathrm{D} 2$ and $\mathrm{D} 3,15 \mathrm{MPa}$ in about $0.5 \mathrm{msec}$ in tests $\mathrm{D} 4$ and D5, and $30 \mathrm{MPa}$ in $0.5 \mathrm{msec}$ in tests D6 and D7. Results for these seven dynamic tests are plotted in Fig. 9b. Finally, dynamic tests D8-DIl were performed with pressure pulses which reached $30 \mathrm{MPa}$ in about $0.3 \mathrm{msec}$; these results are plotted in Fig. 9c. 

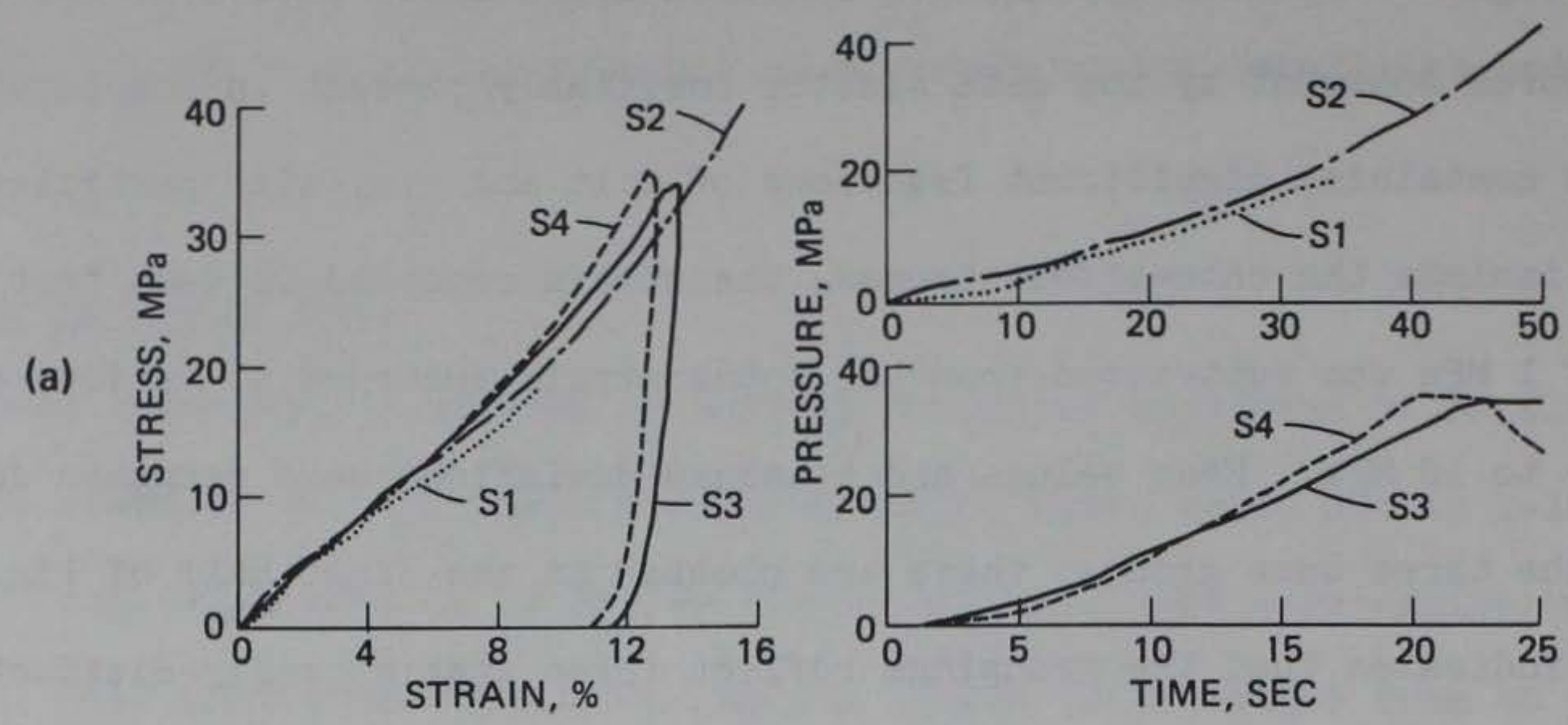

(b)
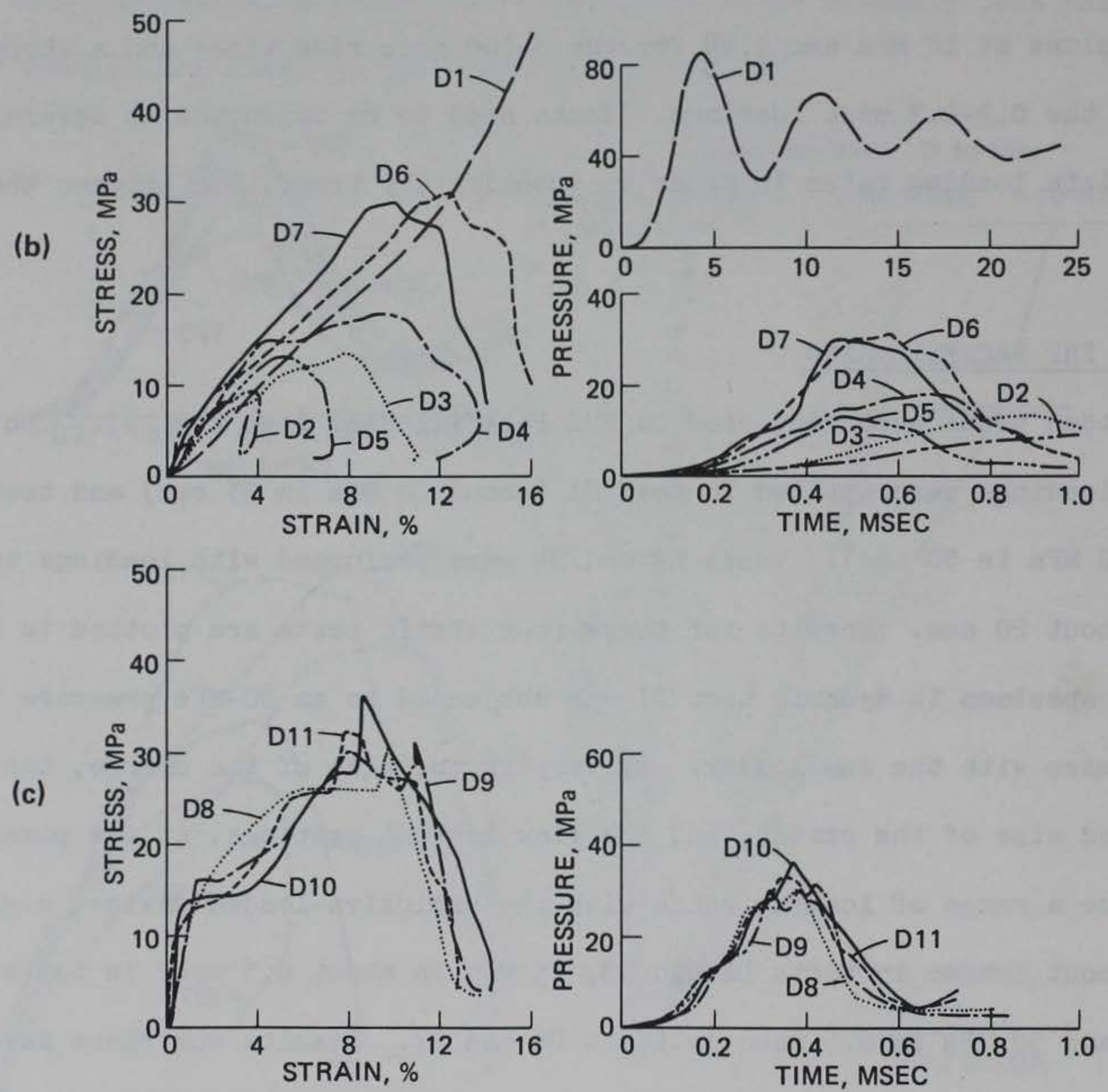

Fig. 9--Uniaxial Strain Test Results for FH2 Backfill Sand. 
The strain recorded at $10 \mathrm{MPa}$ was again chosen as a basis for quantifying loading rate influences on compressibility. The static-to-dynamic strain ratio at $10 \mathrm{MPa}$ for each test is plotted versus loading time in Fig. 10. The plot demonstrates conclusively that, while rate effects on the compressibility of this dry sand can generally be ignored for loading times greater than $1 \mathrm{msec}$, they cannot be ignored for submillisecond loadings, i.e., stiffness increases rapidly as loading time decreases within the 1-msec to $0.1-\mathrm{msec}$ decade. Thus, the suspicions of Whitman (8) appear to have been well-founded. The dynamic-to-static modulus ratios at $30 \mathrm{MPa}$ are not nearly so extreme (a maximum of about 1.5), but the overall stress-strain response shows a marked change in character as the loading rate is increased above about

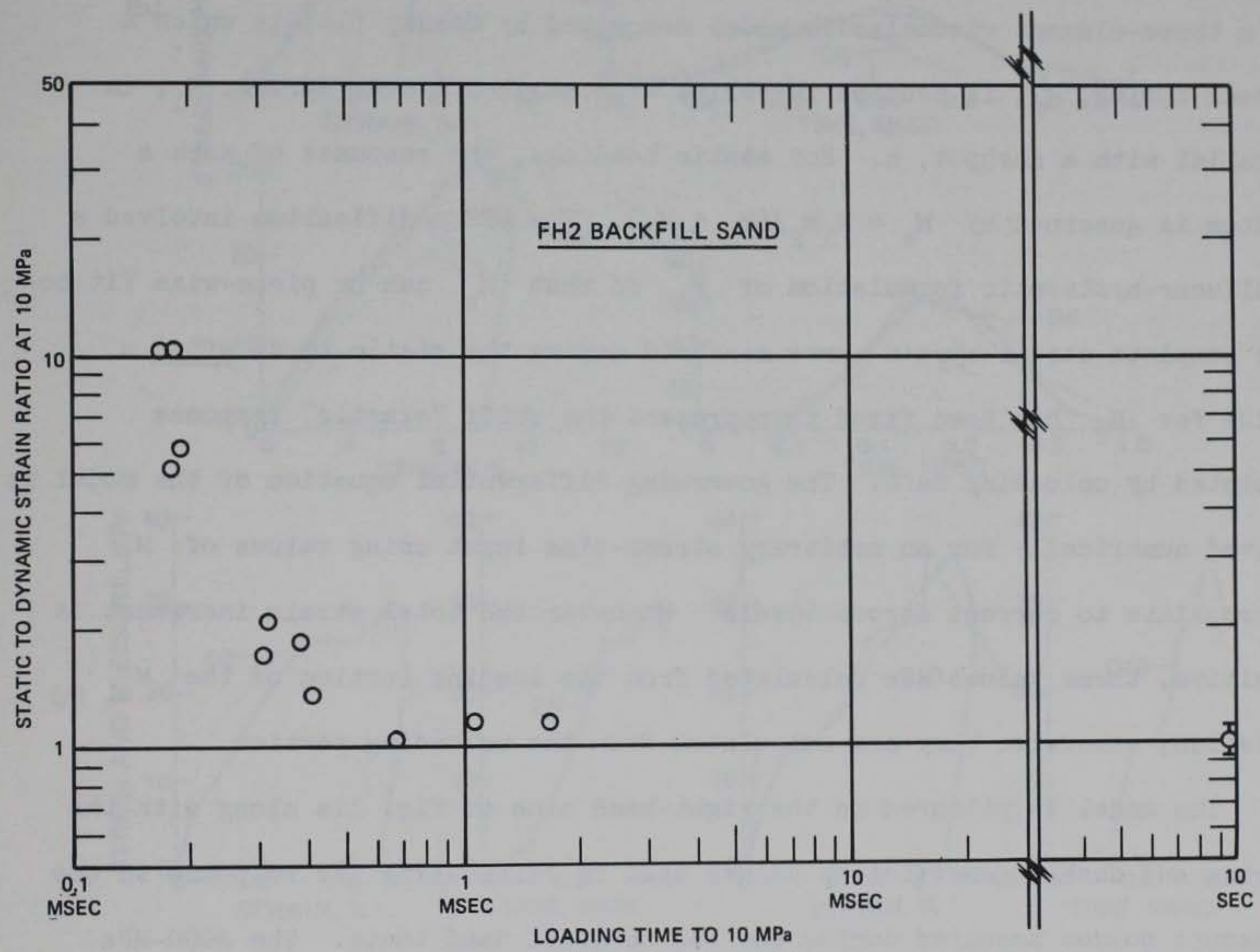

Fig. 10--Effect of Loading Rate on Compressibility of FH2 Backfill Sand. 
$10 \mathrm{MPa} / \mathrm{msec}$. Below this rate, the stress-strain curve "stiffens" (curvature concave to the stress axis), whereas above this rate, the curve "yields" (curvature concave to the strain axis). Such changes in curvature would have significant effects on propagation velocities and rise times at the fronts of blast-induced stress waves $(4,11)$. A variety of simple viscoelastic and hysteretic models have been used to study the effects of time-dependent, inelastic and nonlinear stress-strain behavior on stress wave propagation through laterally confined soils (12, 13); a model incorporating all of these characteristics is needed in order to replicate the behavior shown in Fig. 9.

\section{THREE-ELEMENT RHEOLOGIC MODEL CALCULATIONS}

The three-element rheologic model used in this study is a modified version of a three-element viscoelastic model described by Kolsky (14) in which a linear spring, $\mathrm{M}_{2}$, is coupled in series with another linear spring, $\mathrm{M}_{1}$, in parallel with a dashpot, $n$. For static loadings, the response of such a system is governed by $M_{S}=M_{1} M_{2} /\left(M_{1}+M_{2}\right)$. The WES modification involved a nonlinear-hysteretic formulation of $M_{1}$ so that $M_{S}$ can be piece-wise fit to the complete stress-strain curve measured during the static tests after a value for $M_{2}$ has been fixed to represent the stiff "elastic" response depicted by unloading data. The governing differential equation of the model is solved numerically for an arbitrary stress-time input using values of $M_{1}$ appropriate to current stress levels. Whenever the total strain increment is positive, these values are calculated from the loading portion of the $M_{S}$ relation; otherwise they are calculated from the unloading portion.

The model is pictured on the right-hand side of Fig. 1la along with the spring and dashpot coefficient values used in calculating its response to the pressure pulses measured during the FH2 Backfill Sand tests. The 2000-MPa value for $M_{2}$ was obtained from the static unloading data; $M_{1}$ was derived 
(a)

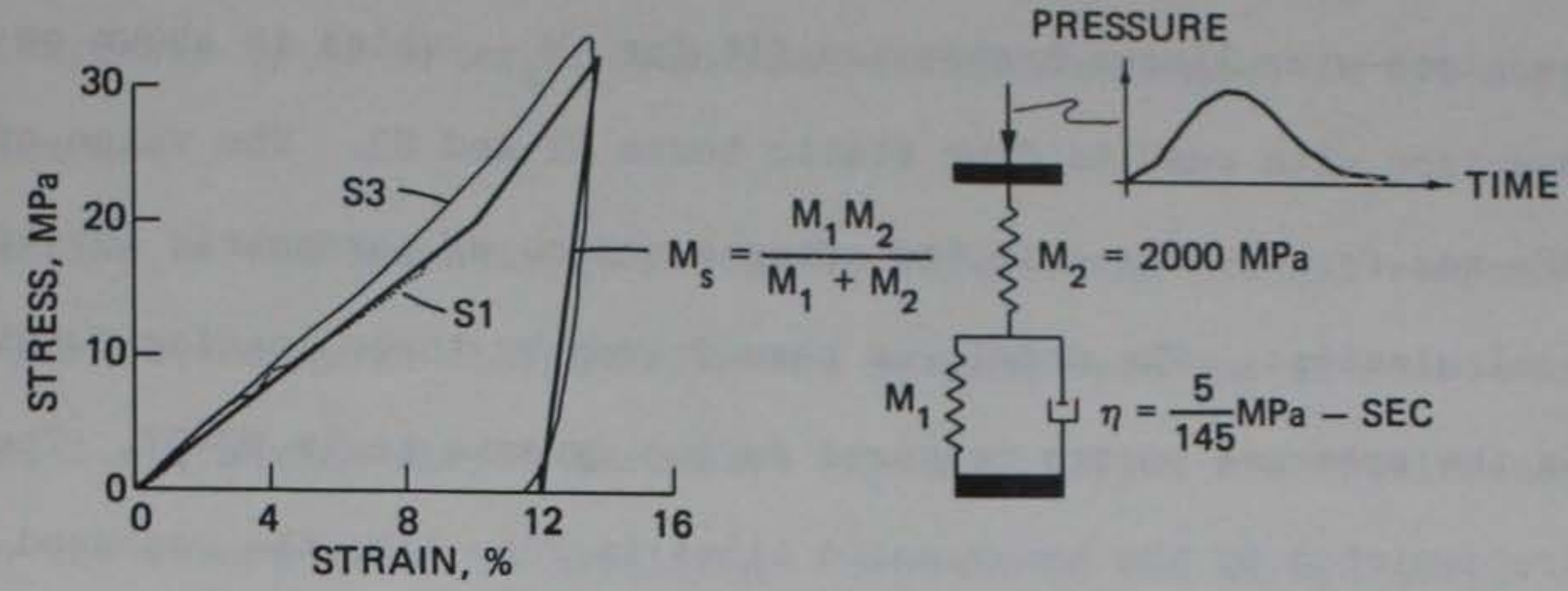

(b)
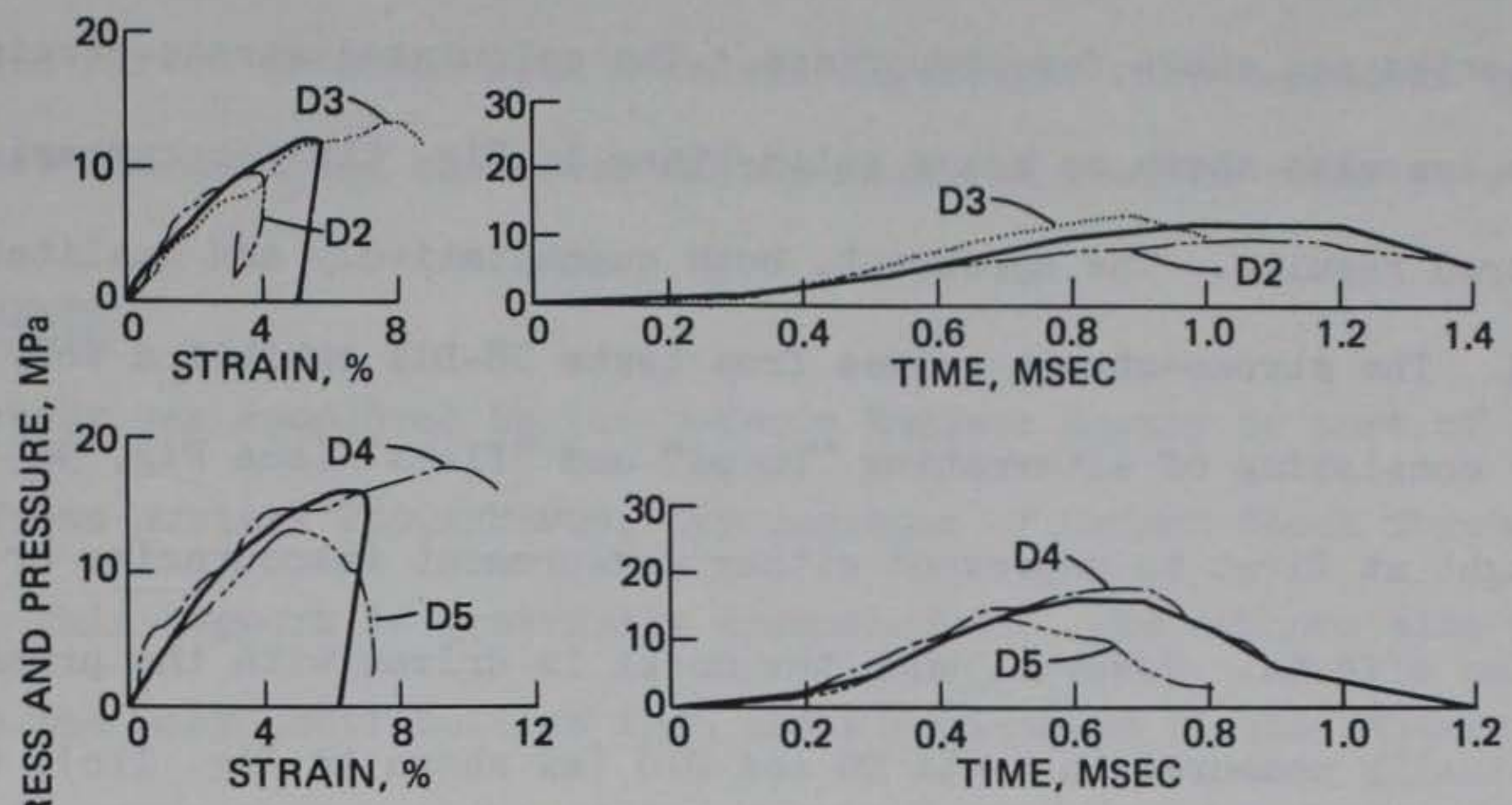

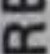
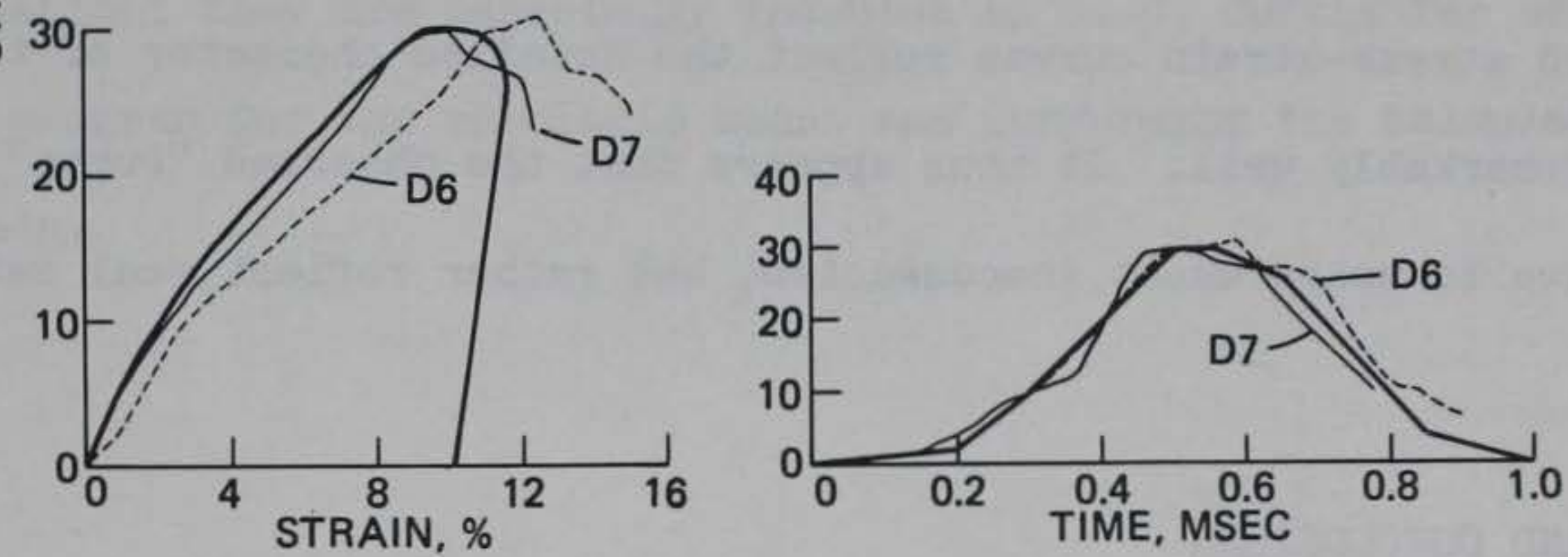

(c)
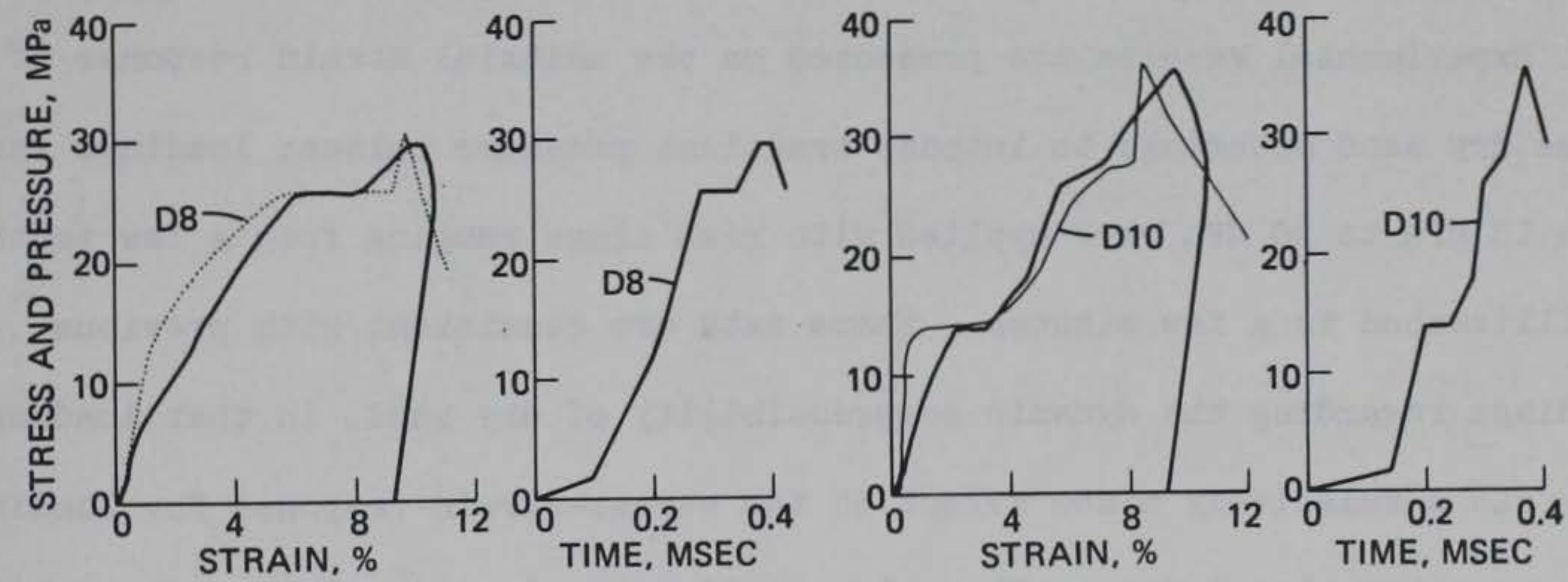

Fig. 1l--Comparison of Three-Element Rheologic Model Response with Stress-Strain Results for FH2 Backfill Sand. 
from the piece-wise linear hysteretic fit for $M_{s}$, which is shown on the left for comparison with results from static tests SI and S3. The value of $5 / 145 \mathrm{MPa}-\mathrm{sec}$ for $n$ was selected after a series of parametric (or trial-anderror) calculations. The model was then driven by three loading functions based on the pressure pulses measured during dynamic tests D2-D7. These functions are depicted by the heavy solid lines in Fig. 11b; the measured pressuretime histories are shown for comparison. The calculated stress-strain responses are also shown as heavy solid lines in Fig. 1lb for comparison with the measured results. The agreement, both quantitatively and qualitatively, is very good. The stress-strain curves from tests D8-D1l exhibit a very erratic character consisting of alternating "bumps" and "flats" (see Fig. 9c) which were thought at first to represent either measurement inaccuracies or wave propagation effects. However, when the model is driven with the pressure-time pulses actually measured in tests D8 and D10 (as shown in Fig. Ilc), the calculated stress-strain curves reflect the detailed character of the measured results remarkably well. It thus appears that the observed "bumps" and "flats" are not due to measurement inaccuracies, but rather reflect real rate-dependent behavior.

\section{SUMMARY AND CONCLUSIONS}

Experimental results are presented on the uniaxial strain response of three dry sand materials to intense transient pressure pulses; loadings ranging from $10 \mathrm{MPa}$ to $80 \mathrm{MPa}$ were applied with rise times ranging from a few tenths of a millisecond to a few minutes. These data are consistent with previous findings regarding the dynamic compressibility of dry sand, in that loading rate had a relatively minor effect on the stress-strain response for loading times greater than $1 \mathrm{msec}$. They also confirm previous suspicions that this would not be the case for submillisecond loadings, in that secant modulus values 
at $10 \mathrm{MPa}$ increased by an order of magnitude within the 1-msec to $0.1-\mathrm{msec}$ rise-time decade.

In addition to the dramatic quantitative effect, the overall response depicted a marked change in character as the loading rate was increased above $10 \mathrm{MPa} / \mathrm{msec}$, i.e., stress-strain curvature rapidly shifted from "stiffening" (concave to the stress axis) to "yielding" (concave to the strain axis). Stress-strain curves obtained with a relatively simple rate-dependent rheologic model reflect the detailed character of the measured results remarkably well.

\section{ACKNOWLEDGMENTS}

This study was sponsored by the Defense Nuclear Agency as part of Nuclear Weapons Effects Subtask Y99QAXSB209, "Propagation of Ground Shock Through Soils and Rock." This support is gratefully acknowledged. The authors also wish to acknowledge the many contributions from their colleagues at the Waterways Experiment Station; they are especially indebted to J. 0. Curtis for developing the computer program for the rheologic model and performing the calculations reported herein. 
1. Whitman, R. V., et al, "The Response of Soils to Dynamic Loads; Report 3, First Interim Report on Dynamic Soil Tests," Publication 104, Soil Engineering Division, Massachusetts Institute of Technology, Cambridge, Mass., to U. S. Army Engineer Waterways Experiment Station, Oct., 1959.

2. Whitman, R. V., "The Response of Soils to Dynamic Loadings; Report 17, Stress-Strain-Time Behavior of Soil in One-Dimensional Compression," Research Report R63-25, Department of Civil Engineering, Massachusetts Institute of Technology, Cambridge, Mass., to U. S. Army Engineer Waterways Experiment Station, May, 1963.

3. Schindler, L., "An Improved Facility for Testing Soils in One-Dimensional Compression," Proceedings, International Symposium on Wave Propagation and Dynamic Properties of Earth Materials, University of New Mexico, Albuquerque, N. Mex., Aug., 1967, pp. 847-860.

4. Whitman, R. V., Miller, E. T., and Moore, P. J., "Yielding and Locking of Confined Sand," Journal of the Soil Mechanics and Foundations Division, ASCE, Vol. 90, No. SM4, Proc. Paper 3966, July, 1964, pp. 57-84.

5. Moore, P. J., "The Response of Soils to Dynamic Loadings; Report 21, OneDimensional Compression and Wave Propagation," Research Report R63-43, Department of Civil Engineering, Massachusetts Institute of Technology, Cambridge, Mass., to U. S. Army Enginẹer Waterways Experiment Station, Oct., 1963.

6. Schindler, L., "Design and Evaluation of a Device for Determining the One-Dimensional Compression Characteristics of Soils Subjected to ImpulseType Loads," thesis presented to the University of Illinois, at Urbana, Ill., in 1968, in partial fulfillment of the requirements for the degree of Doctor of Philosophy in Civil Engineering (subsequently published as Technical Report S-68-9, U. S. Army Engineer Waterways Experiment Station, Vicksburg, Miss., Nov., 1968).

7. Jackson, J. G., Jr., "Physical Property and Dynamic Compressibility Analysis of the Watching Hill Blast Range," Technical Report S-72-4, U. S. Army Engineer Waterways Experiment Station, Corps of Engineers, Vicksburg, Miss., April, 1972.

8. Whitman, R. V., "The Response of Soils to Dynamic Loadings; Report 26, Final Report," Contract Report No. 3-26, U. S. Army Engineer Waterways Experiment Station, Corps of Engineers, Vicksburg, Miss., May, 1970.

9. Hendron, A. J., Fulton, R. E., and Mohraz, B., "The Energy Absorption Capacity of Granular Materials in One-Dimensional Compression," Technical Report SWC-TDR-62-91, Air Force Special Weapons Center, Kirtland Air Force Base, N. Mex., Jan., 1963.

10. Radhakrishnan, N., and Rohani, B., "A One-Dimensional Plane Wave Propagation Code for Layered Nonlinear Hysteretic Media," Technical Report S-71-12, U. S. Army Engineer Waterways Experiment Station, Corps of Engineers, Vicksburg, Miss., Nov., 1971. 
11. Stoll, R. D., and Ebeido, I. A., "Shock Waves in Granular Soil," Journal of the Soil Mechanics and Foundations Division, ASCE, Vol. 91, No. SM4, Proc. Paper 4406, July, 1965, pp. 107-125.

12. Whitman, R. V., "Effects of Viscosity and Inelasticity upon Stress Waves through Confined Soil," Proceedings, 32nd Symposium on Shock, Vibration, and Associated Environments, Office of the Director of Defense Research and Engineering, Vol. II, Aug, 1963.

13. Seaman, L., "One-Dimensional Stress Wave Propagation in Soils," Technical Report DASA 1757, Stanford Research Institute, Menlo Park, Calif., to Defense Atomic Support Agency, Feb., 1966.

14. Kolsky, H., Stress Waves in Solids, Dover Publications, Inc., New York, N.Y., 1963, and Clarendon Press, Oxford, 1953, pp. 114-116. 